\title{
有鉤骨に発生した孤立性骨囊腫の一症例
}

\author{
熊本大学整形外科 \\ 土 屋 立 昭・米 村 憲 輔 \\ 東一成・家入浩一 \\ 高木克 公
}

\section{Solitary Bone Cyst in Hamate Bone \\ A Case Report -}

by

\author{
Tatsuaki Tsuchiya, Kensuke Yonemura, Issei Higashi, \\ Kouichi Ieiri and Katsumasa Takagi \\ Department of Orthopedic Surgery, \\ Kumamoto University Medical School, Kumamoto, Japan
}

\begin{abstract}
Solitary bone cyst is a common lesion at the proximal metaphysis of the long bones such as the humerus and femur. It also occurs in other bones although low frequency. We recently experienced a 19-year-old girl with a bone cyst in the hamate bone. She complained of pain on motion of her wrist. CT clearly demonstrated the lesion in the bone. Bone filling was performed as surgical treatment. This is an interesting case since the occurrence in a carpal bone is considerably rare.
\end{abstract}

孤立性骨囊腫は通常長管骨骨幹端，とくに上腕骨近 位部・大腿骨近位部に好発する。今回われわれは，比 較的まれな発生部位である手根骨に発生した孤立性骨 囊腫の一例を経験したので若干の考察を加えて報告す る.

症例 : 19 才, 女性

主訴：右手関節部運動時痛

家族歷・既往歷：特記すべきことなし

現病歴：中学 1 年, 13 才時よりソフトボールのピッ チャーを続けている。昭和 61 年末頃より, 投球時に右 手関節部痛が出現した。昭和 62 年 6 月頃より症状憎悪 したため，近医を受診、レントゲン上，右有鉤骨内に 囊腫様病変を指摘され当科へ紹介された。右手関節部 には, 疼痛・圧痛・腫脹・発赤・局所熱感・ROM 制限 などみられず，握力にも異常を認めなかった，血液検 查上も，とくに異常は認めなかった。

レントゲン所見：右有鈎骨内に境界明瞭な骨透亮像 を認め，周囲に軽度の骨硬化，皮質のひ薄化を認めた (図 1).

断層像：右有鉤骨内に多房状を呈する骨透亮像が明
瞭に認められる(図 2)。

CT 所見：右有鉤骨内に多房骨性の Low Density Area を認める (図 3 ). 以上の所見より，右有鉤骨の 孤立性骨囊腫と診断し手術を施行した。

手術所見：骨皮質表面にはとくに異常を認めなかっ た。開空すると少量の黄色透明の液の流出が認められ た。内壁には線維性被膜は存在せず，骨性の壁であっ た。腸骨より海綿骨を採取し，骨充填を行った。術後 5 カ月の現在, 疼痛なく順調に経過している.

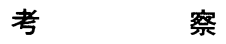

通常, 骨囊腫は漿液性の液体を含み内壁には線維性 被膜を有している11.しかしながら，まれにはまったく 液体の貯溜をみないもの, あるいは線維性被膜の存在 しない単なる空洞もみられる ${ }^{4) 5}$. 今回の症例において も線維性被膜はまったく存在していなかった。このよ うな報告例は他にも散見され，骨囊腫の特殊な型と考 えられる。

孤立性骨囊腫は，骨腫瘍および類似疾患では比較的 頻度の高い疾患であるが，大部分は上腕骨あるいは大 

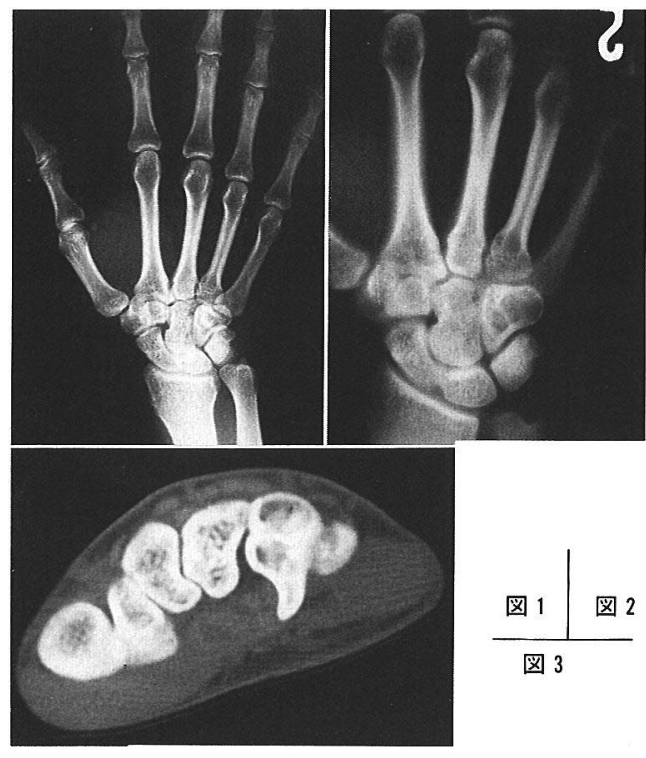

図 1 (単純レントダン像) 有鉤骨内に境界明瞭な骨透亮像を認める。

図 2 (断層レントゲン像) 有鈎骨内に多房状を呈する骨透亮像が明瞭に認 められる。

図 3 (CT 像)

有鉤骨内に多房性の Low Density Area を認め る。

腿骨にその発生をみる。ちなみに，全国骨腫瘍患者登 録一覧表によれば 1964 年から 1986 年までの 23 年間の 統計で孤立性骨囊腫患者は総数 3,213 例であり，その うち手根骨発生は 37 例 $1.2 \%$ である.これは発生部位

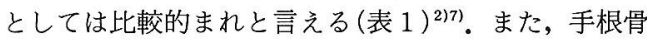
発生の骨腫湟は，同期間中 68 例で全体のわずか $0.2 \%$ にすぎずきわめてまれである。しかしながら孤立性骨 囊腫はそのなかの 37 例 $54.4 \%$ 占め，手根骨発生骨 腫湯においては頻度が高い(表 2$)^{7)}$.

骨囊腫の成因に関して，新陳代謝障害説，腫瘍説， 巨細胞腫の治癒過程とする説，外傷説，炎症説，骨形 成・発育障害説，局所の静脈還流障害説など種々の説 があるが，いまだ定説をみない。しかし最近では局所 の静脈還流障害説が広く支持されてきている5 .当症例 は，ソフトボールを 13 才時より続けており手根部に mild trauma を頻回に受けていたと想像される。諸家 の報告によると骨囊腫患者に明らかな外傷の既往を有 するものは少なく成因としては考え難いとされるが，
表 1 孤立性骨糞腫の発生部位部位別頻度

\begin{tabular}{ccc|r}
\hline \hline 上 & 腕 & 骨 & 1,062 例 $(33.1 \%)$ \\
橈 & & 骨 & 46 例 $(1.4 \%)$ \\
尺 & & 骨 & 27 例 $(0.8 \%)$ \\
手 & 根 & 骨 & 37 例 $(1.2 \%)$ \\
中 & 手 & 骨 & 18 例 $(0.6 \%)$ \\
指 & & 骨 & 30 例 $(0.9 \%)$ \\
腸 & & 骨 & 116 例 $(3.6 \%)$ \\
大 & 腿 & 骨 & 787 例 $(24.5 \%)$ \\
脛 & & 骨 & 158 例 $(4.9 \%)$ \\
腓 & & 骨 & 106 例 $(3.3 \%)$ \\
足 & 根 & 骨 & 637 例 $(19.8 \%)$ \\
\hline 総 & & 数 & 3,213 例 \\
\hline
\end{tabular}

（1964～1986年全国骨腫瘍患者登録一覧表）

表 2 手根骨に於ける骨腫崵別発生頻度

\begin{tabular}{l|r}
\hline \hline Osteochondroma & 5例 $(7.4 \%)$ \\
Enchondroma & 7 例 $(10.3 \%)$ \\
Giant Cell Tumor & 3 例 $(4.4 \%)$ \\
Solitary Bone Cyst & 37 例 $(54.4 \%)$ \\
Metastatic Tumors & 4 例 $(5.9 \%)$ \\
\hline \multicolumn{1}{c|}{ 総 } & 68 例 \\
\hline
\end{tabular}

（1964～1986年全国骨腫瘍患者登録一覧表）

頻回の mild trauma が局所の静脈還流障害をひき起こ す一因となる可能性も否定できないのではないかと思 われる。

手根骨骨囊腫の治療法としては, 諸家の報告ではほ とんどが骨移植を行っており結果はおおむね良好であ $ろ^{3) 6)}$. 一般的に孤立性骨囊腫の治療としては，ステロ イド注入，囊腫壁穿孔術などから搔爬・骨移植あるい は Subtotal resectionまで各種の方法が行われている。 今回の症例においては，有鉤骨鉤部まで囊腫が拡大し ており病的骨折の発生が危惧された。その場合，骨瘾 合が得られ難く偽関節形成の可能性があり，また屈筋 腱断裂や尺骨神経深枝麻㽻などの合併症も生じる可能 性があるため，骨移植は妥当であると考える。

$$
\text { ま と め }
$$

今回われわれは，比較的まれな発生部位である有鉤 骨に発生した孤立性骨囊腫を経験したので，若千の考 察を加えて報告した。

\section{参 考 文 献}

1) Harlan, J., Spjut, M. D. et al.: Tumors of Bone and Cartilage. Armed Forces Institute of Pathology. 
Washington, D. C. 20306, 1970

2）原田 誠・他：手根骨（有頭骨）に発生した孤立性骨 囊腫の 1 例. 整形外科, $21: 294-297,1970$.

3）岸本允男: 大多角骨に発生せる骨囊腫の 1 例. 整形外 科, $21: 1116-1119,1970$.

4）北川敏夫・他：骨囊腫の種々相. 整形外科と災害外科, $28: 174-177,1979$.

5）前田富士雄：孤立性骨囊腫に関する研究 とくにその 成因に関する考察. 日整会誌，37：529-547，1963.

6）森岡庫一・他：手根骨に発生した孤立性骨囊腫の 1 例. 整形外科, $36: 216-218,1985$.

7）全国骨腫瘍患者登録一覧表．国立癌センター，1986。

質 問 久留米大学 中島 稚典

(1) 孤立性骨囊腫との診断ですが，定義はどうして

\section{判断されましたか？}

(2) 手関節の疼痛はどうのような機序とお考えです か?

解 答 熊本大学 土屋 立昭

(1) 定義上，液体を含む骨の空洞を骨囊腫と言うこ とより診断した，定型例では内壁に線維性被膜を有す るが，当症例ではみられず，非定型例と考える。

(2) 疼痛の原因は明確ではない. 手術後, 疼痛消失 しており，骨囊腫が原因と考えられる。 